\title{
GEOLOGIA E TECTÔNICA DA REGIÃO DA FOLHA TOPOGRÁFICA DE JUQUITIBA EM 1:50.000, SUDESTE DO ESTADO DE SÃO PAULO
}

\author{
TECTONIC AND GEOLOGY OF THE REGION OF THE JUQUITIBA TOPOGRAFIC SHEET IN \\ 1:50.000, SOUTHEAST OF THE STATE OF SÃO PAULO
}

\author{
Antonio Misson GODOY ${ }^{1}$; Marcos Aurélio Farias de OLIVEIRA ${ }^{\mathbf{1}}$; Peter Cristian \\ HACKSPACHER ${ }^{1}$; Otávio Augusto Ruiz Paccola VIEIRA ${ }^{2}$, Jefferson Cassu MANZANO ${ }^{3}$ \\ ${ }^{1}$ Departamento de Petrologia e Metalogenia- IGCE- UNESP- Universidade Estadual Paulista. Rio Claro (SP), Brasil. \\ Emails: mgodoy@rc.unesp.br, maurelio@ rc.unesp.br, phack@rc.unesp.br \\ ${ }^{2}$ Pós-Graduação em Geociências- IGCE- UNESP- Universidade Estadual Paulista. Email: otaviovieirageo@gmail.com \\ ${ }^{3}$ Mineração Rio Tinto. E-mail: manzanojc@gmail.com
}

\author{
Introdução \\ Geologia Regional \\ Geologia \\ Interpretação Aerogeofísica \\ Complexo Embu \\ Caracterização Tectônica \\ Caracterização Metamórfica \\ Conclusões \\ Agradecimentos \\ Referências
}

\begin{abstract}
RESUMO - O mapeamento das unidades litológicas da Folha Topográfica de Juquitiba em escala de 1:50.000 é resultado da integração e realização de levantamentos geológicos. A área está localizada a sudoeste da cidade de São Paulo e inserida na Província Mantiqueira Central, porção central do Cinturão Ribeira. Compreende uma pequena região, a norte da Zona de Cisalhamento Caucaia-Rio Jaguari, constituída pelas rochas do Bloco Cotia e, a maior área, por rochas do Bloco Juquitiba. A região é caracterizada por litotipos rochosos metassedimentares migmatizados, compostos de migmatitos, gnaisses e xistos aluminosos, além de anfibolitos, metarenitos e rochas calciossilicatadas, de idade meso- a neoproterozoica, do Complexo Embu; inúmeros granitos e corpos de pegmatitos peraluminosos do tipo S, complexos graníticos cálcio-alcalinos do tipo I Ibiúna e Caucaia de idade neoproterozoica e sedimentos recentes quaternários. A evolução tectono-metamórfica consiste de deformações/metamorfismo progressivo $\mathrm{D}_{1} / 2$ tangenciais, associados ao processo colisional, e pela tectônica transcorrente/transpressiva $\mathrm{D}_{3}$, de direção NE-SW, marcada por uma foliação milonítica vertical. O metamorfismo regional progressivo é do tipo Barroviano, com rochas em fácies anfibolito alto e ocorrências locais de metamorfismo de contato, além do metamorfismo dinâmico que apresenta natureza retrometamórfica.

Palavras-chave: Complexo Embu, paragnaisses, mapeamento geológico, região de Juquitiba.
\end{abstract}

\begin{abstract}
Geological mapping of the Juquitiba Topographic Sheet lithological units in 1: 50.000 scale is the result of integration and realization of geological surveys. The area is located southwest of São Paulo city and inserted in the Central Mantiqueira Province, central portion of the Ribeira Belt. It comprises a small region, north of the Caucaia-Rio Jaguari Shear Zone, constituted by the Cotia Block rocks and, the largest area, by the Juquitiba Block rocks. The region contains metasedimentary migmatized rock lithotypes, migmatitos, gneiss and aluminous schists, in addition to amphibolites metasandstones and calcium-silicate rocks, all of Meso to Neoproterozoic age, belonging to the Embu Complex; numerous peraluminous S type granites and pegmatites bodies; Neoproterozoic I Type calc-alkaline granite bodies of the Ibiúna and Caucaia complexes; and recent quaternary sediments. The tectono-metamorphic evolution shows $\mathrm{D}_{1 / 2}$ tangential deformations/progressive metamorphism, associated to collisional process, and $\mathrm{D}_{3}$ transcurrent/transpressive tectonics, NE-SW direction, marked by intense vertical milonitic foliation and smooth to open regional folds. The progressive regional metamorphism is of the Barrowian type, with high amphibolite facies rocks and contact metamorphism local, as the retrometamorphism caused by dynamic metamorphism nature.
\end{abstract}

Keywords: Embu Complex, paragneiss, geological mapping, Juquitiba region.

\section{INTRODUÇÃO}

A região geográfica da Folha Topográfica de Juquitiba (SF-23-Y-C-V-4) em 1:50.000 do Instituto Brasileiro de Geografia e Estatística IBGE, 1984, encontra-se localizada a sudoeste da região Metropolitana de São Paulo, limitada pelas coordenadas $23^{\circ} 45^{\prime}$ e $23^{\circ} 00^{\prime}$ de latitude sul e $47^{\circ} 15^{\prime}$ e $47^{\circ} 00^{\prime}$ de longitude oeste. Este trabalho é resultado da integração de mapeamentos e levantamentos geológicos na Folha Piedade em 1:100.000, constituída pelas quatro folhas topográficas em 1:50.000: São Roque, Sorocaba, Jurupara e Juquitiba, a partir do convênio PRONAGEO-CPRM e IGCE/UNESP.
A geologia desta região foi inicialmente caracterizada nos seguintes mapas: Mapa Geológico do Estado de São Paulo, editado pelo Instituto Geográfico e Geológico, em escala 1:1.000.000 de 1963 e de 1974; em Hasui (1973), no trabalho de mapeamento das folhas topográficas de São Roque e Pilar do Sul em escala 1:100.000, em Algarte et al. (1973) no Projeto Sudeste do Estado de São Paulo; em Bistrichi et al. (1981) e Almeida et al. (1981) no mapa geológico de integrações do estado de São Paulo em escala 1:500.000, elaborados pelo Instituto de Pesquisa Tecnológica - IPT e em Chieregati et al. (1991), no 
Projeto Integração Geológica da Região Metropolitana de São Paulo.

A integração mais atualizada da área encontra-se em Perrotta et al. (2005) no mapa em escala 1: 750.000 elaborado pela Companhia de Pesquisa de Recursos Minerais.

A região se localiza na Província Mantiqueira Central (Almeida, 1967; Almeida \& Hasui, 1984; Hasui \& Oliveira, 1984; Heilbron et al., 2004), na faixa central do Cinturão Ribeira (Cordani et al., 1973) e, mais especificamente, na parte norte do Bloco ou Terreno Embu (Hasui, 1975; Tassinari, 1988). Este terreno define um grande compartimento geotectônico a partir da movimentação horizontal e vertical de zonas de cisalhamento de idade neoproterozoica, com rejuvenescimento tardio.

Segundo Hasui et al. (1978) e Hasui \& Oliveira (1984), o contato norte deste terreno se faz com a Zona de Cisalhamento Taxaquara, que o coloca lado a lado com o Domínio São Roque, e pela Zona de Cisalhamento Agudos Grandes, fazendo contato, na região sudoeste, com o Domínio Apiaí, e a sul, com a Zona de Cisalhamento Cubatão, com as rochas do Domínio Costeiro.

Atualmente, o Terreno Embu foi redefinido, sendo seu contato norte considerado como a Zona de Cisalhamento Caucaia-Rio Jaguari. É cortado transversalmente pela Zona de Cisalhamento Taxaquara-Guararema, em contato com o Terreno Açunguí (Silva, 2017).
A região é constituída por rochas de idade meso- a neoproterozoica do Complexo Embu, onde predominam os litotipos supracrustais metamorfizados em fácies anfibolito alto, constituídos dominantemente por paragnaisses e xistos migmatíticos, além de possíveis e raros gnaisses ortoderivados.

Associadas à expressiva ocorrência das rochas paraderivadas, observam-se rochas graníticas neoproterozoicas, constituídas pelos granitos cálcioalcalinos do Tipo I, definidos pelos complexos Ibiúna e Caucaia, e os inúmeros granitos peraluminosos do Tipo S, de pequeno porte, sendo que os maiores apresentam denominações locais, propostas por Hasui (1973). Estes granitos peraluminosos encontram-se agrupados nos mapas atuais como granitos peraluminosos indiferenciados. Além destas litologias, apresentam-se na área inúmeros corpos de pegmatitos aluminosos e os sedimentos quaternários.

Este trabalho tem o propósito de apresentar os dados resultantes da investigação geológica e estrutural da área geográfica da Folha Topográfica de Juquitiba, que foram inicialmente trabalhadas a partir de mapeamentos com alunos do curso de Geologia do IGCE-UNESP, e integrações a partir de subsídios da Companhia de Pesquisa de Recursos Minerais, definindo, assim, as principais unidades litotectônicas (tectono-metamórficas) separadamente, em termos de sua evolução petrológica, magmática-metamórfica e estrutural.

\section{GEOLOGIA REGIONAL}

A Província Mantiqueira desenvolveu-se durante a Orogenia Neoproterozoica BrasilianaPan Africana, que amalgamou microplacas ou terrenos e resultou na construção do Paleocontinente Gondwana Ocidental (Heilbron et al., 2004). Um evento final que encerrou o Ciclo Brasiliano foi o do colapso gravitacional e exumação de orógenos, marcando a passagem de condições de forte atividade compressiva, para as de estabilização dos orógenos.

A Província Mantiqueira foi subdivida inicialmente por Almeida et al. $(1977,1981)$ em três grandes setores, referidos como Setentrional, Central e Meridional. Respectivamente, estes setores passaram a ser referidos como correspondente a três cinturões orogênicos: Araçuaí, Ribeira e Tijucas por Hasui et al. (1978), Hasui (2010) e Hasui et al. (2012).

O Cinturão Ribeira (Hasui, 2010, 2012) é dividido em sete terrenos: Varginha, Embu,
Costeiro, São Roque, Apiaí, Curitiba, Paranaguá e Luiz Alves, de origens distintas e separados por zonas de cisalhamento (Campanha, 2002; Heilbron et al., 2004; Faleiros, 2008; Faleiros et al., 2011; Santos et al., 2015). Sua estruturação é controlada por um sistema de cisalhamento transcorrente destral (Campanha, 1991; Campanha \& Sadowski, 1999; Campanha, 2002; Faleiros, 2008; Faleiros et al., 2010, 2011). Essas grandes zonas de cisalhamento compartimentam a região em grandes blocos tectônicos delimitados por falhas, o que colocou unidades de idades diferentes lado a lado (Hasui et al., 1969).

Segundo Heilbron et al. (1995), o segmento central da Faixa Ribeira apresenta uma evolução definida em quatro principais unidades litotectônicas: o embasamento pré-1.800Ma; os ortognaisses com posicionamento temporal não definido; a cobertura metassedimentar pós $1.800 \mathrm{Ma}$; e as rochas granitoides brasilianas. 
O Neoproterozoico da parte central do Cinturão Ribeira é marcado pela intensa granitogênese formadora do Arco Magmático Rio Negro (Heilbron et al., 2004). O estudo dos granitoides pós-orogênicos a anorogênicos da Faixa de Dobramento Ribeira foi inicialmente proposto por Hasui et al. (1978), que individualizou os inúmeros corpos graníticos pós-tectônicos do estado de São Paulo. Segundo Prazeres Filho et al. (2003), o período pós-colisional anorogênico é marcado pela intrusão de plútons graníticos rasos.

A partir do trabalho de Hennies et al. (1967), surgiram as primeiras ideias de compartimentação tectônica do Pré-Cambriano no Estado de São Paulo, com base em falhamentos transcorrentes separando blocos crustais. O falhamento de Taxaquara delimita os blocos Cotia e São Roque. A norte do Bloco São Roque, o falhamento de Jundiuvira delimita o Bloco Jundiaí, proposto por Hasui et al. (1969). Coutinho, (1971) e Coutinho et al. (1972), a sul do Bloco Cotia, a partir do falhamento de Cubatão, individualizam o Bloco Costeiro, inicialmente definido por Almeida (1953).

A partir da denominação por Hasui (1973) de Conjunto São Roque permitiu-se a subdivisão, através dos falhamentos de Taxaquara e Caucaia, nos blocos Itupararanga e Juquitiba. Sadowski (1974) definiu na região da Serra de Cubatão dois blocos: Juquitiba, proposto inicialmente por Hasui (1973) e Litorâneo, sendo este último correspondente ao Bloco Costeiro (Coutinho, 1971 e Almeida, 1953). Hasui (1975) subdividiu o Bloco São Roque, proposto por Hennies et al. (1967), nos Blocos Itupararanga (Hasui, 1973), Pirapitingui, Moreiras e Juqueri.

Hasui \& Sadowski (1976) propuseram uma estruturação em quatro blocos justapostos, agrupando diferentes blocos geológicos em conjuntos, denominando-os, de leste para oeste: o Conjunto Costeiro a leste da Falha de Cubatão e correspondendo ao Bloco Costeiro; de Conjunto Paranapiacaba entre as falhas de Cubatão e de Taxaquara, constituído pelos blocos Juquitiba e Cotia e composto pelas litologias dos complexos Pilar e Embu; o Conjunto São Roque entre as falhas de Taxaquara e Itu/Jundiuvira, proposto por Hasui (1973); e de Conjunto Jundiaí, a norte do falhamentos de Itu-Jundiuvira.

O Complexo Embu foi definido pela primeira vez como unidade litoestratigráfica por Hasui
(1975) e Hasui \& Sadowski (1976), como subdivisões do Grupo Açunguí, limitados a norte pela Zona de Cisalhamento Caucaia - Rio Jaguari e a sul pela Zona de Cisalhamento Cubatão. Campos Neto \& Basei (1983) dividiram o PréCambriano paulista e propuseram o termo conjuntos e que os mesmos se subdividem em blocos. Neste sentido, foram mantidos nos domínios do Conjunto Paranapiacaba os Blocos Cotia e Juquitiba, tal como proposto por Hennies et al. (1967) e Hasui (1973).

Tassinari (1988) propõe a divisão da Faixa Ribeira, na porção sudeste do estado de São Paulo, em cinco domínios com evoluções geológicas distintas e que se confrontam: Itapira-Amparo, Piracaia-Jundiaí, São Roque, Embu e Costeiro.

Tassinari \& Campos Neto (1988) propõe para a região a divisão em cinco grandes terrenos ou domínios de norte para sul: a Faixa Alto Rio Grande (Hasui \& Oliveira, 1984) constituído por ortognaisses e migmatitos; a Nappe SocorroGuaxupé (Campos Neto et al., 1984), composta por rochas de alto grau metamórfico e granitos associados de idade neoproterozoica; o Domínio São Roque (Tassinari \& Campos Neto, 1988), constituído por metassedimentos de baixo a médio grau dos grupos São Roque e Serra do Itaberaba; o Domínio Embu composto por supracrustais e granitos; e o Domínio ou Complexo Costeiro caracterizado por rochas granulíticas, migmatíticas e graníticas, divisão que que será utilizada no decorrer do texto.

As áreas do embasamento no Estado de São Paulo foram divididas por Janasi \& Ulbrich (1991, 1992) em oito domínios estruturais alongados, limitados por importantes falhas transcorrentes: São Roque, Açunguí, Embu, Ubatuba, Iguape, Guaxupé, Jundiaí e Amparo.

De uma forma sucinta, devido a diversidade de denominações propostas, a área em estudo está inserida no compartimento denominado de: Complexo Embu (Hasui, 1975; Hasui et al., 1981), Complexo Embu ou Terreno Embu (Campos Neto, 2000; Heilbron et al., 2004; Alves et al., 2013, 2016; Perrotta et al., 2005) (Figura 1), Bloco Embu (Dantas et al., 1987), Terreno Acrescido Embu (Campos Neto \& Figueiredo, 1995), Domínio Embu (Passarelli et al., 2004) e de Complexo Embu como parte do Terreno Juiz de Fora (Campos Neto, 2000; Passarelli et al., 2004) (Figura 1). 


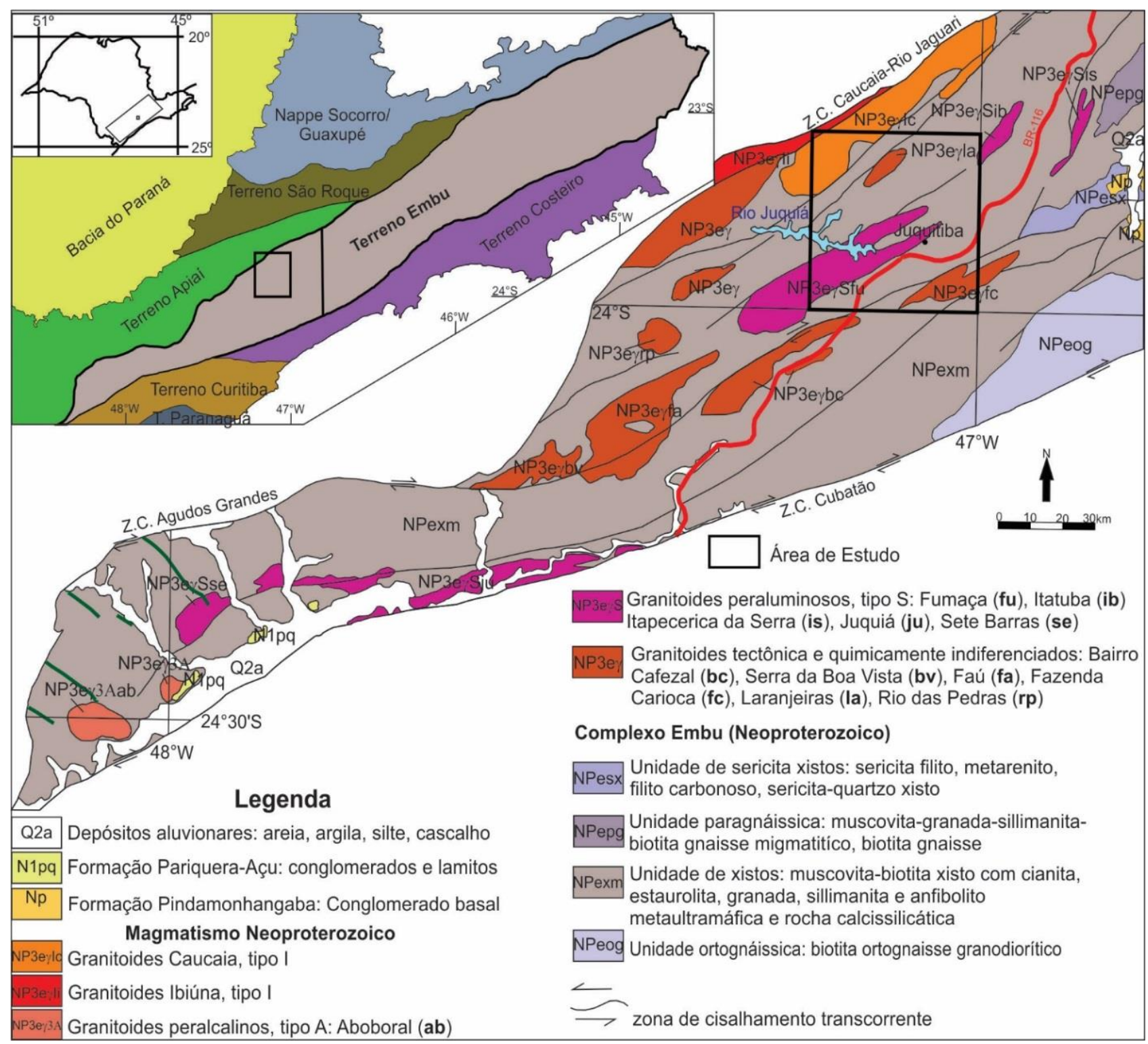

Figura 1 - Mapa Geológico com a distribuição dos diversos terrenos que compõe o estado de São Paulo, com detalhe de parte do Complexo Embu e localização da Folha Topográfica de Juquitiba (Mod. de Perrotta et al. 2005).

Quanto aos aspectos lito-estratigráficos, Hasui (1973), Hasui et al. (1976) e Hasui \& Sadowski (1976) distinguiram duas associações litológicas no Domínio Embu: o Complexo Pilar do Sul e o Complexo Migmatítico Embu.

O primeiro formado principalmente por rochas metassedimentares de baixo grau metamórfico, o segundo por xistos e gnaisses migmatíticos. Hasui (1973) propôs a anexação do Complexo Pilar ao Complexo Embu, assim redefinido como uma única sequência com diferentes graus de migmatização pertencente ao Grupo Açunguí.

Sobreiro Neto et al. (1983), em trabalhos na Carta Geológica do Estado de São Paulo em 1:50.000, estendeu o Complexo Embu para a região da Folha de São Luiz do Paraitinga.
$\mathrm{Na}$ região de Embu-Guaçu, distinguem-se dois conjuntos metassedimentares, que compõem faixas com direção geral NE-SW e que se diferenciam, principalmente, com relação ao grau metamórfico e ao tipo de intercalações que apresentam.

Assim, foram definidas duas unidades: a unidade dos xistos rítmicos, informalmente denominada unidade dos xistos Santa Rita, que abriga rochas calciossilicáticas, anfibolitos e rochas meta-ultramáficas; e a unidade dos sericita xistos e filitos (Vieira, 1989).

Perrotta et al. (2005), no Mapa Geológico do Estado de São Paulo, escala 1:500.000, dividem as rochas do Complexo Embu nas unidades Ortognáissica, Xistos, Paragnáissica e Sericita Xistos. 
Os principais litotipos do Complexo Embu são biotita-granada gnaisses, xistos, migmatitos, gnaisses calciossilicáticos, quartzitos, anfibolitos e ortognaisses (Oliveira et al., 1998). Possuem rochas na forma de lentes ou faixas, com orientação ENE-WSW e são representadas por metassedimentos migmatizados em maior ou menor grau, com intercalações de biotitagranada com ou sem sillimanita, mica xistos, paragnaisses parcialmente migmatizados e quartzitos (Passarelli et al., 2004).

Na porção sudeste do estado de São Paulo, este complexo compreende, principalmente, mica xistos, xistos finos, filitos, metabasitos, rochas calciossilicáticas, paragnaisses migmatizados (metatexitos a diatexitos) e quartzitos (Passarelli et al., 2004).

No Domínio Embu, de idade neoproterozoica, ocorrem expressivos granitos cálcio-alcalinos e abundantes granitos fortemente peraluminosos, formando várias ocorrências menores, que indicam a participação predominante ou exclusiva de material derivado de crosta continental (Janasi et al., 2003).

Trabalhos recentes encontram-se principalmente na região nordeste de São Paulo, as litologias do Complexo Embu são agrupadas em três unidades estratigráficas principais: Rio Uma, Rio Paraibuna e Redenção da Serra, pertencentes ao Complexo Rio Capivari, proposto por Meira (2014), Maurer (2016) e Silva (2017). O Domínio Embu é constituído por:

- rochas do Complexo Embu caracterizado por uma unidade de ortognaisses, que apresentam a idade entre 810 e $780 \mathrm{Ma}$, obtidas através de métodos SHRIMP, U-Pb em zircão por Cordani et al. (2002);

- rochas metassedimentares que apresentam idade máxima de deposição inferida a partir da idade do zircão detrítico mais jovem, de 980 Ma, no Toniano, com a concentração das idades principalmente no Mesoproterozoico, entre 1,0 e 1,2 Ga, e com um pico secundário em 1,8 Ga (Silva, 2017) e, segundo Vieira \& Tassinari (1988), as rochas metassedimentares apresentam idade $\mathrm{Rb} / \mathrm{Sr}$ de $750 \pm 20 \mathrm{Ma}$. Os dados geocronológicos indicam idade do metamorfismo de 790 Ma para as rochas do Complexo Embu (Vlach, 2001; Cordani et al., 2002; Vieira \& Tassinari, 1988).

Os paragnaisses e migmatitos do Complexo
Embu apresentam valores de $\mathrm{T}_{\mathrm{DM}}$ entre $1.64 \mathrm{e}$ 1.80 Ga (Dantas et al., 1999, 2000; Hackspacher et al., 1999; Hackspacher \& Godoy, 1999).

- granitos cálcio-alcalinos da área, que de acordo com Vieira \& Tassinari (1988), possuem idade $\mathrm{Rb} / \mathrm{Sr}$ de $612 \pm 83 \mathrm{Ma}$. Essa idade é interpretada como a época do "emplacement" dos corpos granitoides em níveis superiores da crosta.

O Complexo Ibiúna é caracterizado por nove fácies granitoides, compostas predominantemente por monzogranitos e subordinadamente por sienogranitos, com raros enclaves de rochas quartzo dioríticas. $\mathrm{O}$ máfico principal é a biotita, seguida por hornblenda e raramente piroxênio (Godoy et al., 1992, 1996, 1999; Gomes \& Godoy, 2002; Hackspacher et al., 1992, 1993, 2000). Descrições acerca deste corpo encontram-se em Hasui (1973, 1975), Hasui et al. (1978), Vlach et al. (1990), Janasi et al. (1990) e Leite (1997).

- Por granitos aluminosos, que correspondem a unidade mais jovem e são representados por pequenas intrusões pegmatíticas nos xistos, gnaisses e metarritmitos do Complexo Embu, com idade K-Ar de $552 \pm 15$ Ma (Vieira \& Tassinari, 1988).

O Maciço Caucaia, assim denominado por Hasui et al. (1973) e caracterizado em Godoy et al. (1992) e Hackspacher et al. (1991, 1992), ocorre a sudeste da ZC Caucaia e é representado por litotipos composicionais correspondentes a sieno- e monzogranitos, sendo reconhecidos tipos texturais equigranulares a inequigranulares, róseos e acinzentados, que constituem uma faixa contínua com orientação geral NE-SW e se estendem a sul para a área da Folha Juquitiba.

A norte, encontra-se em contato tectônico com os metassedimentos do Complexo Embu e com o Granitoide Ibiúna, e a sul, é intrusivo nos referidos metassedimentos.

Entre as rochas ígneas ácidas ocorre um conjunto de corpos menores de granitos aluminosos, apresentando dominantemente feições pegmatíticas, sendo que os maiores e que foram denominados no trabalho de Hasui (1975) como Granito São Sebastião, Granito Fumaça ou Represa do França, Granito Fazenda Carioca, Granito Pedras e Granito Fazenda 3M. 


\section{GEOLOGIA}

O mapeamento da área da Folha Topográfica de Juquitiba (SG-22-X-B-II-2), na escala 1:50.000, resultou inicialmente da integração de mapeamentos geológicos em escala 1: 25.000, executados parcialmente em partes da área da folha por trabalhos de campo realizados por docentes e estudantes da UNESP, Rio Claro, e evoluiu para trabalhos de mapeamento, homogeneização e integração de todas as unidades geológicas e estruturais de toda a área.

A área da Folha de Juquitiba compreende uma pequena região, a norte da Zona de Cisalhamento Caucaia-Rio Jaguari (ZCCR), constituída pelas rochas do Bloco Cotia, caracterizado por metassedimentos de idade meso- a neoproterozoica do Complexo Embu e corpos graníticos de idades neoproterozoicas, do Tipo I, cálcio-alcalinos metaluminosos a peraluminosos, do Complexo Ibiúna.

A sul da ZCCR, define-se a maior área de trabalho, caracterizada pelas rochas do Bloco Juquitiba, identificado na área dominantemente pelas rochas metassedimentares do Complexo Embu, pelas rochas graníticas cálcio-alcalinas do Complexo Caucaia, pelos inúmeros granitos e corpos de pegmatitos do tipo $\mathrm{S}$ peraluminosos e depósitos aluvionares recentes.

O Complexo Embu compreende uma considerável variedade de litotipos, sendo que as rochas ortoderivadas constituem as mais antigas e de pequena expressão, no limite externo da Folha Juquitiba, na Br-116, nas proximidades da cidade homônima e caracterizada por rochas ortognáissicas.

$\mathrm{Na}$ área, ocorrem rochas metabásicas de localização restrita e na forma de duas pequenas lentes, a norte de Juquitiba.

A sequência metassedimentar é dominante em toda área. É constituída de migmatitos paraderivados de ocorrência localizada e que gradam lateralmente para paragnaisses; rochas gnáissicas metassedimentares de grande expressão dominando a metade norte da área e que transicionam e apresentam localizadamente feições migmatíticas; e xistos aluminosos, que dificilmente são encontrados frescos, dominando a metade sul da área.

Na sequência de gnaisse e xisto paraderivados observa-se passagem localizada e, às vezes, transicionais para níveis apresentando intensidade variável de migmatização ou para áreas de domínio restrito de metarenitos e rochas calciossilicatadas (Figura 2).

\section{Interpretação Aerogeofísica}

A figura $3 \mathrm{~A}$ refere-se à localização da Folha Topográfica de Juquitiba e os projetos inicialmente consultados para a realização do mapeamento. A figura 3B apresenta a imagem com o modelo digital de relevo SRTM (Sutlle Radar Topographic Mission) e a figura 3C a representação dos principais domínios tectônicos. A área da Folha Juquitiba é constituída por terrenos pré-cambrianos mesoproterozoicos caracterizados por rochas metassedimentares e plutônicas ácidas do tipo $\mathrm{S}$ indiferenciadas, além rochas graníticas neoproterozoicas, ambas alinhadas com o trend regional NE-SW, além das formações sedimentares superficiais.

A interpretação qualitativa dos dados aerogeofísicos, de magnetometria e gamaespectrometria teve como objetivo auxiliar os trabalhos da cartografia geológica da Folha Juquitiba. De modo geral, o estudo restringiu-se à análise de feições geofísicas, a partir dos contrastes laterais de propriedades físicas apresentadas pelos minerais existentes nas litologias do terreno.

O mapa de gamaespectrometria (Figura 3D) permite a caracterização da geologia de superfície e representa a distribuição de diferentes rochas e solos aflorantes, a partir de radioatividade acima do background, como granitoides e feições com radiação decrescente ou com baixas emissões de radiação gama.

O mapa gamaespectrométrico da Folha Juquitiba (contagem total), no geral, apresentase com um índice relativamente alto de radioelementos.

Poucas são as regiões onde a concentração de radioelementos é baixa. Destaca-se a região a noroeste da área, onde a concentração de elementos radiométricos torna-se muito elevada, principalmente com relação ao elemento potássio, observado pela tonalidade vermelha, na caracterização do Granito Caucaia e São Sebastião.

O mapa aeromagnetométrico (Figura 3E) foi de grande contribuição acerca de informações relacionadas à geologia estrutural da área, podendo ser útil para definição do arcabouço tectonoestrutural da região. 


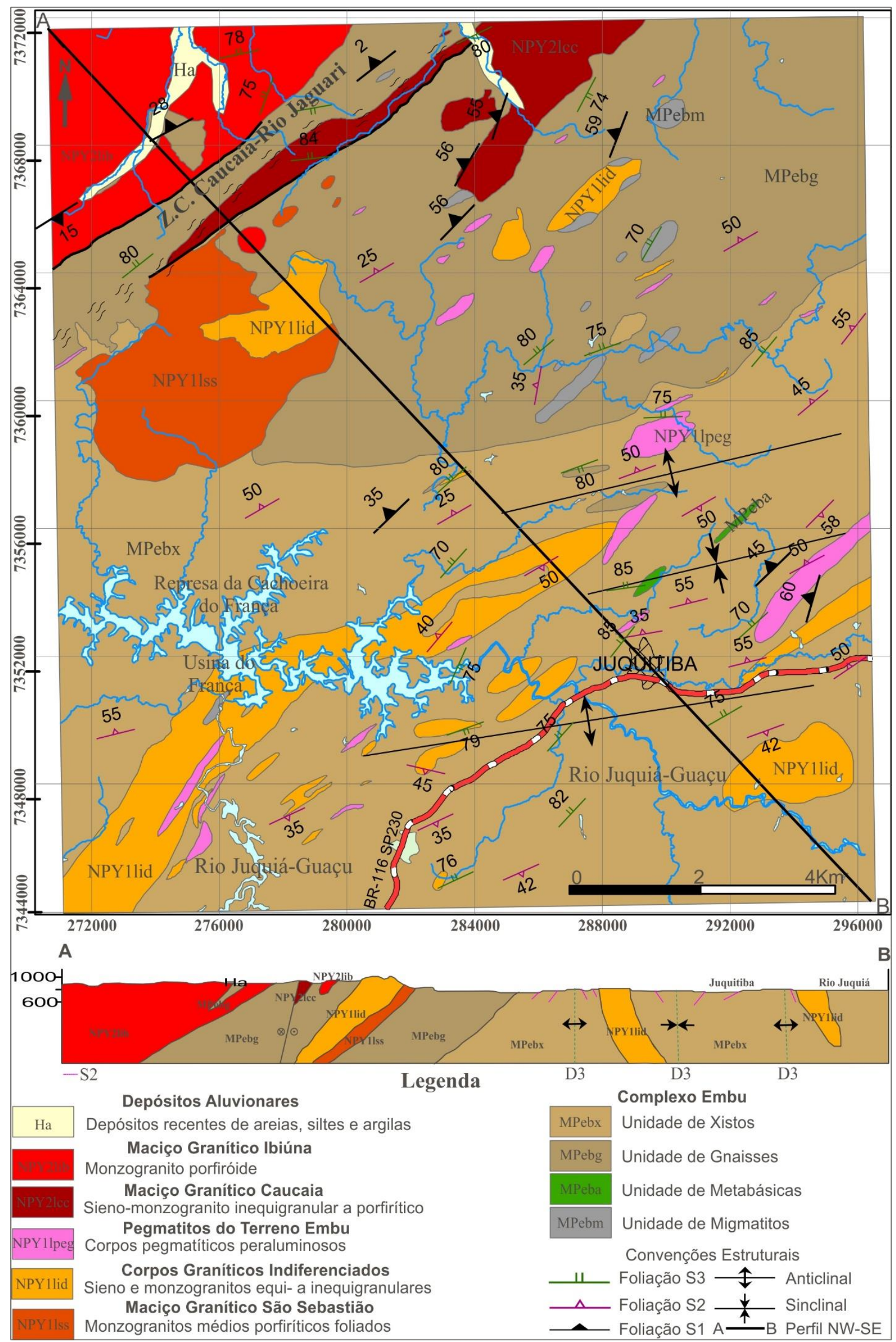

Figura 2 - Mapa Geológico da área da Folha Topográfica de Juquitiba em 1:50.000. 


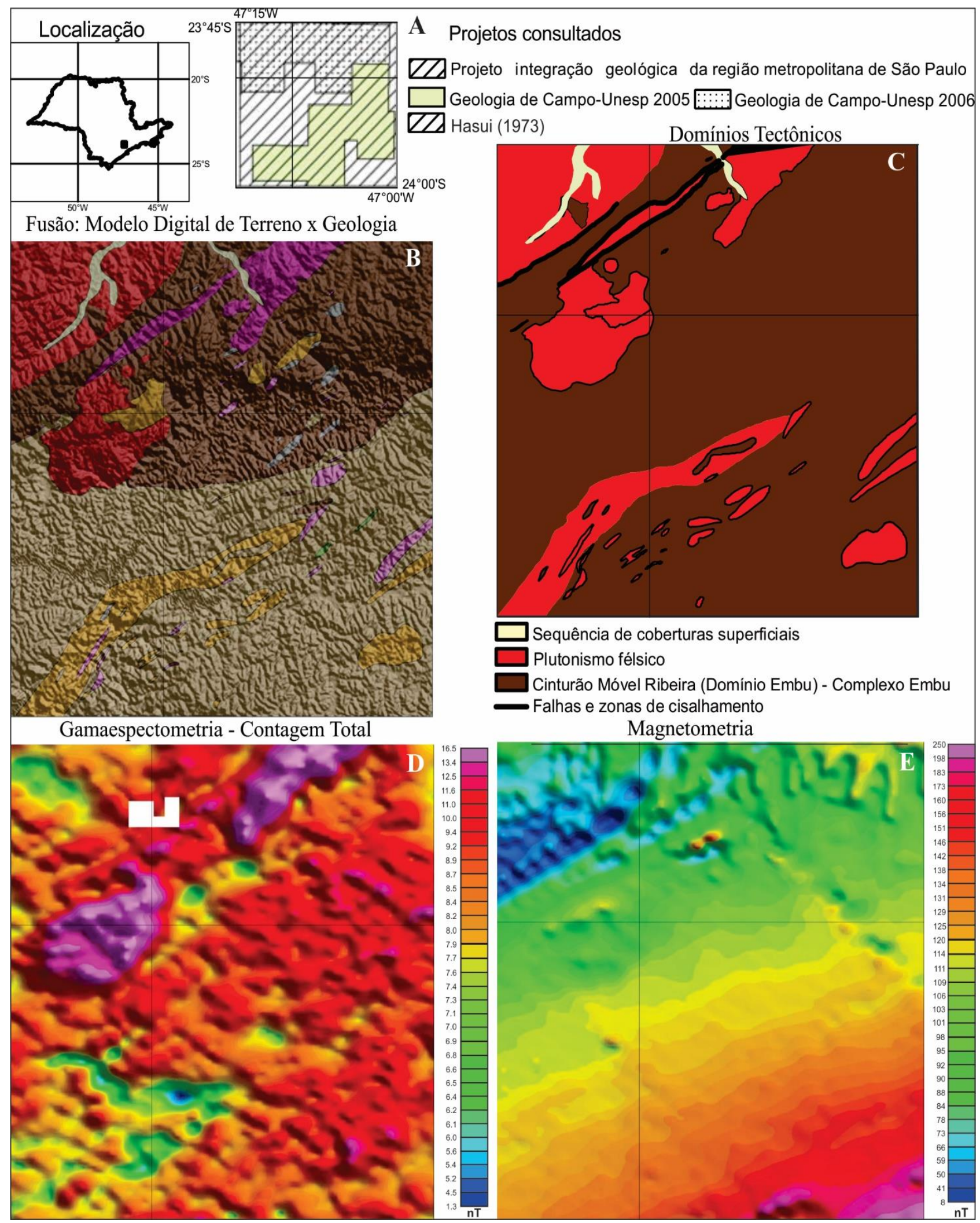

Figura 3: A) Mapa de localização e projetos consultados na Folha Topográfica de Juquitiba, B) Fusão: Modelo Digital de Terreno x Geologia, C) Mapa dos Domínios Tectônicos, D) Mapa de Gamaespectrometria - Contagem Total, E) Mapa Aeromagnetométrico.

Nota-se uma característica comum a esse tipo de mapa, que é a bipolaridade, pela existência de valores positivos (em vermelho), os quais representam anomalias magnéticas do campo total geradas por corpos magnetizados, associados a valores negativos (em azul).

Percebe-se que a predominância de alinhamentos magnéticos associados às falhas/fraturas dá-se na direção NE-SW; porém, existe um alinhamento magnético perpendicular 
na região nordeste da folha, de grande expressão, cortando o trend principal dos alinhamentos magnéticos.

\section{Complexo Embu}

A Unidade de Migmatitos são representados na área por um conjunto de rochas metassedimentares e normalmente ocorre associada a ocorrências locais de gnaisses e de xisto. São migmatitos com estruturas bandadas estromáticas, oftalmítica e schlieren. São compostos por microclínio, quartzo, oligoclásio, biotita, sillimanita, granada e, como minerais acessórios, apatita, titanita, zircão, além de, como minerais secundários, muscovita, sericita, clorita, epidoto, leucoxênio, óxidos e hidróxidos. É possível observar a passagem dos metassedimentos para migmatitos, com o contato entre paleossoma e neossoma podendo ser gradual, sendo provável que, boa parte dessa unidade, seja o resultado da anatexia dos paragnaisses.

Apresentam uma expressiva heterogeneidade, com domínios ricos em biotita, sillimanita e quartzo, estrutura xistosa e textura lepidoblástica ou finamente laminada. Tipos rítmicos também são encontrados na área, definidos por faixas escuras micáceas ou avermelhadas quando alteradas, compostas por cristais bem desenvolvidos de biotita e muscovita, além de porfiroblastos de granada, sillimanita prismática, estaurolita, fibrolita, turmalina, feldspatos, apatita, zircão, óxidos e hidróxidos de ferro. São intercalados em faixas mais claras, essencialmente quartzosas, com textura granoblástica.

A Unidade de Metabásicas constituem por ocorrência de raras intrusivas máficas e ultramáficas e são representadas, respectivamente, por pequenos corpos de anfibolito e de epidoto-actinolita-clorita xistos. Os anfibolitos representam corpos dispersos, todos com dimensões reduzidas e restritas, como pequenas lentes disruptas em meio às rochas metassedimentares, concordantes com a foliação. O maior corpo de rocha metabásica ocorre a $3 \mathrm{~km}$ a norte de Juquitiba, constituído pela mineralogia essencial de labradoritaandesina, hornblenda e raros cristais de pseudomorfos de augita, biotita e quartzo. Os principais minerais acessórios são titanita, apatita, minerais opacos, zircão e raramente granada, enquanto os minerais secundários estão caracterizados por epidoto, actinolita, clorita, sericita e hidróxidos.

$\mathrm{O}$ epidoto-actinolita-clorita xisto ocorre na forma de corpos lenticulares, alongados e orientados segundo a foliação principal na área, constituídos por actinolita-tremolita, clorita, biotita, minerais opacos e apatita.

A Unidade de Gnaisses constitui a litologia dominante na região norte da área e é constituída dominantemente por paragnaisses apresentando estrutura bandada e contendo intercalações de biotita gnaisses com ou sem sillimanita e granada, biotita xistos e localmente de gnaisses calciossilicatados e quartzitos. Frequentemente apresentam feições de intensidade variáveis de processos migmatíticos ou gradam localmente para rochas xistosas e ou para faixas tectonizadas de paragnaisses miloníticos, ou ainda, em lentes restritas e descontínuas de rochas calciossilicáticas e quartzitos. Uma ocorrência representativa deste conjunto rochoso é observada junto ao Rio Juquiá, na região da Usina Hidroelétrica da Cachoeira do França.

Os paragnaisses constituem as litologias dominantes nesta unidade e ocorrem em forma de corpos alongados, associados aos xistos e migmatitos. Apresentam, comumente, estruturas bandadas a laminadas, com alternância de leitos milimétricos a decimétricos com predomínio de quartzo, microclínio, oligoclásio e biotita, além de quantidades variadas de sillimanita, muscovita, granada e, mais raramente, anfibólio. A estrutura é gnáissica a xistosa e bandada ou lenticular.

São, portanto, rochas derivadas de sedimentos pelíticos, psamo-pelíticos, calciossilicatados, psamíticos e possivelmente grauvaqueanos, que atingiram condições metamórficas acima da curva de fusão parcial, gerando remobilizados graníticos e pegmatoides sin-tectônicos e possíveis injeções graníticas

A Unidade de Xistos constitui as rochas dominantes na parte sul da área e ocorrem na forma de lentes, ou representam o paleossoma dos migmatitos, com espessuras centimétricas a métricas, ou bandas nos gnaisses, para os quais gradam com o aumento da proporção de feldspatos. Intercalados nos gnaisses, ocorrem subordinadamente níveis centimétricos de mica xistos, com ou sem granada e sillimanita, ou ainda lentes descontínuas de rochas cálcios- 
silicáticas, quartzitos e anfibolitos.

Os xistos são compostos por biotita, muscovita, quartzo, além de plagioclásio, microclínio, granada, sillimanita, clorita, minerais opacos, turmalina, clorita, sericita, leucoxênio, clinozoisita/epidoto e, mais raramente, anfibólio.

Localmente, e de ocorrência restrita, observase nas proximidades dos corpos graníticos a ocorrência de corpos de turmalina-muscovitabiotita xisto. Esporadicamente, nesta área é possível observar turmalinito na forma de camada centimétrica, composta essencialmente por turmalina, quartzo e muscovita.

Nesta unidade é observado localmente: metarenitos constituindo níveis ou camadas descontínuas, lentes ou boudins, com espessuras decimétricas a métricas, normalmente apresentando contatos gradacionais ou bruscos; xisto apresentando níveis mais enriquecidos em granada, gerando níveis gondíticos, xistos quartzosos e, finalmente, lentes de metarenitos de granulação mais fina e ricos ainda em biotita e muscovita.

As rochas calciossilicáticas são de ocorrência generalizada na área, mas em nenhum local encontrou-se uma ocorrência espessa dessa rocha. Normalmente são granoblásticas quartzosas e constituem lentes, camadas descontínuas e boudins nos paragnaisses e xistos.

Os minerais principais são representados por quartzo, plagioclásio cálcico e, em menores proporções, clinopiroxênio, anfibólio, granada, epidoto/clinozoisita, titanita, feldspato potássico, biotita, escapolita, minerais opacos, apatita, zircão e allanita, além dos de alteração, clorita, actinolita, muscovita/sericita, carbonato, leucoxênio e hidróxidos. Localmente, observase a transição para quartzitos calciossilicáticos.

Feições semelhantes a metarritmitos são observadas localmente e em faixas organizadas na direção NE-SW e são o resultado de intenso processo milonítico, que reduz a granulação dos minerais micáceos e reorganiza as mineralogias em um bandamento tectônico de alto ângulo.

Neste conjunto de gnaisse e xistos intercalam-se rochas pegmatíticas, mais abundantes nas proximidades das intrusões graníticas. Afloram sob a forma de corpos métricos a decamétricos ou como veios deformados cortando os xistos e gnaisses, ora de modo discordante, ora concordante, mas em geral, dando a estas rochas $\mathrm{o}$ aspecto de migmatitos. Muitas vezes estes corpos pegmatoides se confundem com o leucossoma das rochas migmatizadas, ambos com mineralogias extremamente aluminosas.

Os granitos e pegmatitos aluminosos correspondem a unidade mais jovem e são caracterizados na área por inúmeros corpos, sendo que o maior, o Maciço Granítico São Sebastião, será descrito e os demais pelo seu tamanho encontram-se descritos em Corpos Graníticos Indiferenciados.

O Granito São Sebastião é constituído por leucogranito inequigranular a porfirítico, com predominância de grãos de tamanho médio a fino, que ocorre sob a forma principal de um corpo ovalado e os menores alongados, podendo apresentar foliação milonítica e subparalelos à Zona de Cisalhamento Caucaia-Rio Jaguari de direção geral NE. É constituído por rochas inequigranulares, de granulação predominantemente média, com grãos de feldspato atingindo até $1 \mathrm{~cm}$ de comprimento, inseridos em matriz quartzo-feldspática com biotita e composta por aproximadamente $35 \%$ de quartzo, $30 \%$ de feldspato potássico, $25 \%$ de muscovita e $10 \%$ de biotita

Os Corpos Graníticos Indiferenciados encontram-se inseridos diversos corpos graníticos aluminosos de pequeno porte, sendo que alguns apresentam denominações de localidades da área e foram apresentadas por Hasui (1973).

O Granito Fumaça ou da Represa do França é representado por sieno- a monzogranitos foliados, peraluminosos, tipo $S$, que se encontram intrudidos em paragnaisses e xistos, localmente migmatíticos.

O Granito Fazenda Carioca é composto por granada-muscovita-biotita monzogranito de granulação média, foliado, homogêneo e composto por granada, muscovita, biotita, quartzo, microclínio, muitas vezes saussuritizados, oligoclásio e, como mineral assessório, zircão. Observa-se nessa rocha uma foliação bem nítida, dada pela orientação dos cristais de biotita e muscovita, descrita como foliação $S_{3}$, que é a mais pronunciada na área de mapeamento.

O Granito Pedras corresponde a um biotitamuscovita sienogranito, que tem a forma de um 
corpo alongado. Possui algumas porções pegmatíticas e a exposição das rochas está geralmente alterada. Composto principalmente por quartzo, microclínio, oligoclásio, muscovita e biotita, e, como minerais acessórios, ocorrem zircão, apatita e titanita.

O Granito Fazenda 3M é classificado como um granada-turmalina-muscovita sienogranito, com forma alongada e orientado segundo a direção da foliação principal da área, com feições miloníticas e cataclásticas. É composto por quartzo, microclínio, oligoclásio, muscovita, turmalina, granada e minerais acessórios. Constitui corpo que ocorre encaixado em xistos e na borda são encontrados tipos ricos em turmalina.

Inúmeras variedades de turmalina leucogranitos são identificáveis em toda a área, sem apresentar uma denominação particular, na forma de corpos alongados na direção ENE, ou mesmo na forma de veios cortando as litologias presentes. Tratam-se de sienogranitos com granada, muscovita, raramente biotita e turmalina negra, muitas vezes pegmatíticos, sendo muitos frequentemente explorados para produção de caulim. De maneira geral, as rochas exibem uma estrutura bastante foliada, orientada, fato marcado principalmente pela disposição das micas e turmalinas.

Os pegmatitos aluminosos encontram-se encaixados nas rochas metassedimentares e podem ocorrer como corpos pegmatíticos e raramente como aplíticos. Os pegmatitos apresentam composição basicamente aluminosa, sendo no geral muito ricos em turmalina e muscovita e, em menor proporção, granada, com granulação bem grossa. Esses corpos variam de irregulares a acamadados, entre os xistos e metarenitos.

São compostos geralmente por feldspato potássico, quartzo, plagioclásio, muscovita, quantidades menores de biotita, turmalina e granada. Os cristais de turmalina geralmente estão orientados segundo a direção da foliação principal. Encontram-se muito alterados, sendo muitas vezes explorados de forma rudimentar para caulim ou mesmo exploração de muscovita.

O Maciço Granítico Caucaia são rochas cálcio-alcalinas que se encontram distribuídas na área em um corpo alongado na região $\mathrm{NW}$ da área, com orientação geral NE-SW, determinado na sua maior extensão ao longo da zona de cisalhamento Caucaia. É marcado principalmente por monzogranitos inequigranulares cinza, com feições de reorientação de minerais, principalmente nas proximidades da Zona de Cisalhamento Caucaia-Rio Jaguari.

A granulação destas rochas varia de média a grossa, podendo ser fina quando deformada, fortemente inequigranular, com a presença esporádica de megacristais de microclínio, que perfazem menos de $5 \%$, localmente superior a $10 \%$, com dimensões máximas em torno de 2 $\mathrm{cm}$. Composicionalmente, correspondem a monzogranitos de coloração cinza, essencialmente leucocráticos, com cerca de 5 a $10 \%$ de minerais máficos. Apresentam quartzo, plagioclásio, microclínio, biotita, além de titanita, minerais opacos, apatita, zircão, allanita, epidoto, clorita e sericita.

São frequentes xenólitos, intercalações, leitos e lentes com espessuras que podem ultrapassar uma centena de metros de rochas metassedimentares do Complexo Embu. As intercalações mais espessas ocorrem principalmente nas bordas do corpo. Ao longo do contato com a zona de cisalhamento ocorre espessa faixa de granitóides intensamente deformados com o desenvolvimento de rochas protomiloníticas com direção NE-SW.

O Maciço Granítico Ibiúna é composto por rochas cálcio-alcalinas, sendo a área da folha, ocupada dominantemente pela fácies monzogranito porfiroide serial a hiatal rósea e com pequenas variações litológicas locais que não foram mapeadas nesta escala de trabalho.

Os granitoides Ibiúna distribuem-se como um corpo no extremo NW da área e que fazem parte do contato sul, de uma faixa com disposição geral NE-SW, na forma de corpos parcialmente tectonizados. Frequentemente apresentam superposição de deformação milonítica, que muitas vezes mascara totalmente as feições texturais.

São rochas porfiríticas róseas e cinzas de composição predominante monzogranítica, compreendendo variedades leucocráticas, com granulação da matriz média a grossa. Destacamse as variações do tamanho dos fenocristais de feldspato potássico e suas porcentagens, que variam no intervalo de 20 a $40 \%$, atingindo em média $5 \mathrm{~cm}$. Em algumas regiões, os fenocristais assumem tamanhos próximos a $10 \mathrm{~cm}$, ocorrem em abundância, em matriz muito grosseira, 
significando feições pegmatóides de ocorrência local. O tamanho dos fenocristais apresenta predominantemente disposição serial, mas com domínio das frações maiores, variando entre 5 e $6 \mathrm{~cm}$, e uma sempre menor que $2 \mathrm{~cm}$.

São constituídas por microclínio (35\%), oligoclásio (25\%), quartzo (25\%), biotita (10\%), hornblenda e Ferro-hastingsita (5\%), minerais opacos, apatita, rutilo, zircão e titanita, além de sericita, epidoto e clorita.

Localmente, em menores expressões, ocorrem rochas graníticas tardias representadas por monzogranitos equigranulares e inequigranulares médios.

Os Depósitos aluvionares não foram individualizados para toda a área.

\section{CARACTERIZAÇÃO TECTÔNICA}

A evolução das rochas da Folha Juquitiba apresenta um registro dominantemente neoproterozoico, associada inicialmente a uma tectônica colisional, constituída por movimentos crustais convergentes, a partir de eventos tectônicos tangenciais e consequente espessamento de massas crustais. Durante a finalização do processo colisional, ocorreu uma tectônica transcorrente, definida principalmente pelas zonas de cisalhamento de Caucaia e Cubatão, ambas com movimento destral.

As deformações na área são evidenciadas pelo registro de três fases deformacionais (Figura 4) denominadas de $D_{1}, D_{2}, D_{3}$ e associadas aos eventos metamórficos $\mathrm{M}_{1}, \mathrm{M}_{2}$ e $\mathrm{M}_{3}$.

As estruturas primárias ocorrem preservadas de forma escassa nas áreas menos deformadas (Figuras 4A, 5A). São raras devido aos intensos processos de transposição das foliações $S_{1} / S_{2}$ e da deformação milonítica, associadas à deformação de alto ângulo $S_{3}$, passando a um bandamento tectônico nas regiões da zona de cisalhamento.

As rochas do Complexo Embu são intensamente estruturadas com a tectônica de baixo ângulo, portador de uma foliação bem marcada e implantada em condições de fácies anfibolito; em comparação, nas regiões em que predominam uma foliação vertical, ocorre um trend preferencial NE, que reflete uma foliação milonítica penetrativa nas zonas de cisalhamento, com a geração de filonitos, que oblitera total ou parcialmente as foliações anteriores.

Nos xistos e gnaisses do Bloco Embu, tem-se marcada uma foliação sub-horizontal das fases deformacionais $\mathrm{D}_{1} / \mathrm{D}_{2}$, apresentando feição que está relacionada a um regime colisional em fácies anfibolito alto.

As deformações progressivas tangenciais $\mathrm{D}_{1} / \mathrm{D}_{2}$ encontram-se associadas ao início do processo colisional (Figura 5A), com formação de dobras isoclinais fechadas e redobradas a recumbentes, e foliação plano-axial $S_{1}$ de baixo a médio ângulo, paralela a subparalela a $S_{0}$, de atitude preferencial N42E/53NW (Figura 4B), com elementos cinemáticos que indicam transporte principal para noroeste.

A fase $D_{1}$ é observada localmente, com a foliação $S_{1}$ marcada pela envoltória de dobras de crenulação da fase $\mathrm{D}_{2}$. Durante a formação dessa foliação (ou xistosidade), ocorreu a lenticularização e boudinagem de camadas máficas (anfibolito), metarenitos e rochas calciossilicatadas, que, devido ao estiramento, foram rompidas.

$\mathrm{O}$ ápice metamórfico $\mathrm{S}_{1}$ está associado à formação das rochas migmatíticas e é caracterizado pela presença de dobramentos migmatíticos paralelo a uma foliação. No processo de migmatização observa-se a organização paralela de um conjunto mineral metamórfico, observados por sillimanita, muscovita e biotitas. A esta fase associa-se a geração de granitos e pegmatitos aluminosos resultado da fusão de paragnaisse e migmatitos.

$\mathrm{A}$ fase $\mathrm{D}_{2}$ é caracterizada pelo ápice deformacional e definida por uma foliação penetrativa $\mathrm{S}_{2}$, redobramentos assimétricos, gerando uma xistosidade ou gnaissificação (bandamento gnáissico $\mathrm{S}_{2}$ ) com atitude preferencial de N10E/22NW (Figura 4C). As dobras desta fase, observadas na área de mapeamento, são de três tipos: dobras isoclinais, dobras abertas monoclinais e dobras de crenulação.

Esta foliação é bem marcada e é implantada em condições de fácies anfibolito, atingindo isógrada superior da sillimanita e até mesmo fusão parcial, indicando migmatização contemporânea. Nas rochas migmatíticas com paleossomas de rochas metassedimentares é reconhecida uma orientação penetrativa dos minerais micáceos e de minerais 
inequidimensionais, com bandamento e xistosidade paralelos a subparalelos.

$\mathrm{O}$ transporte tectônico da fase $\mathrm{D}_{2}$ é para noroeste. Localmente ocorrem as duas foliações $\mathrm{S}_{1} / \mathrm{S}_{2}$, no entanto, quando paralelizadas, apenas a foliação $S_{2}$ é preservada (Figura 5A). As dobras de crenulação são as mais comuns, ocorrem principalmente em rochas xistosas e de escala centimétrica. Geralmente, são dobras fechadas simétricas, com eixo horizontal a sub-horizontal, mergulhando levemente para SW ou NE.

A granitogênese cálcio alcalina associa-se a uma tectônica dúctil tardi $\mathrm{D}_{2}$ com emplacement dos maciços, que ressalta o caráter sincinemático ao evento tectônico $\mathrm{D}_{2}$.

O quadro deformacional final da área é reconhecido pela implantação da fase $D_{3}$, definida por uma foliação milonítica $S_{3}$ associada à transcorrência destral, de caráter dúctil-rúptil e retrometamórfica. As estruturas de grande porte da área são definidas pela formação de dobras suaves a abertas (sinformais e antiformais) e sanfonadas de eixo subhorizontal NE, com uma tênue clivagem subvertical, com plano axial de atitude N60E/subvertical (Figura 4D) e flancos marcados pelas foliações $\mathrm{S}_{2} / / \mathrm{S}_{1} / / \mathrm{S}_{0}$, evoluindo gradativamente e localmente para falhas direcionais.

A foliação $\mathrm{S}_{3}$ é penetrativa nas zonas de cisalhamento, caracterizando-se como uma foliação milonítica, com a geração de filonitos com acamamento tectônico que oblitera estruturas reliquiares. A verticalização da foliação ocorre por influência das zonas de cisalhamento NE-SW, com mergulhos altos para NW ou SE, permitindo a compartimentação tectônica atual em blocos (Figura 5B). Esta foliação também pode ser vista em corpos graníticos e veios pegmatíticos sin- a tarditectônicos. Muitas vezes a foliação $S_{3}$ é a estrutura mais evidente na área mapeada.

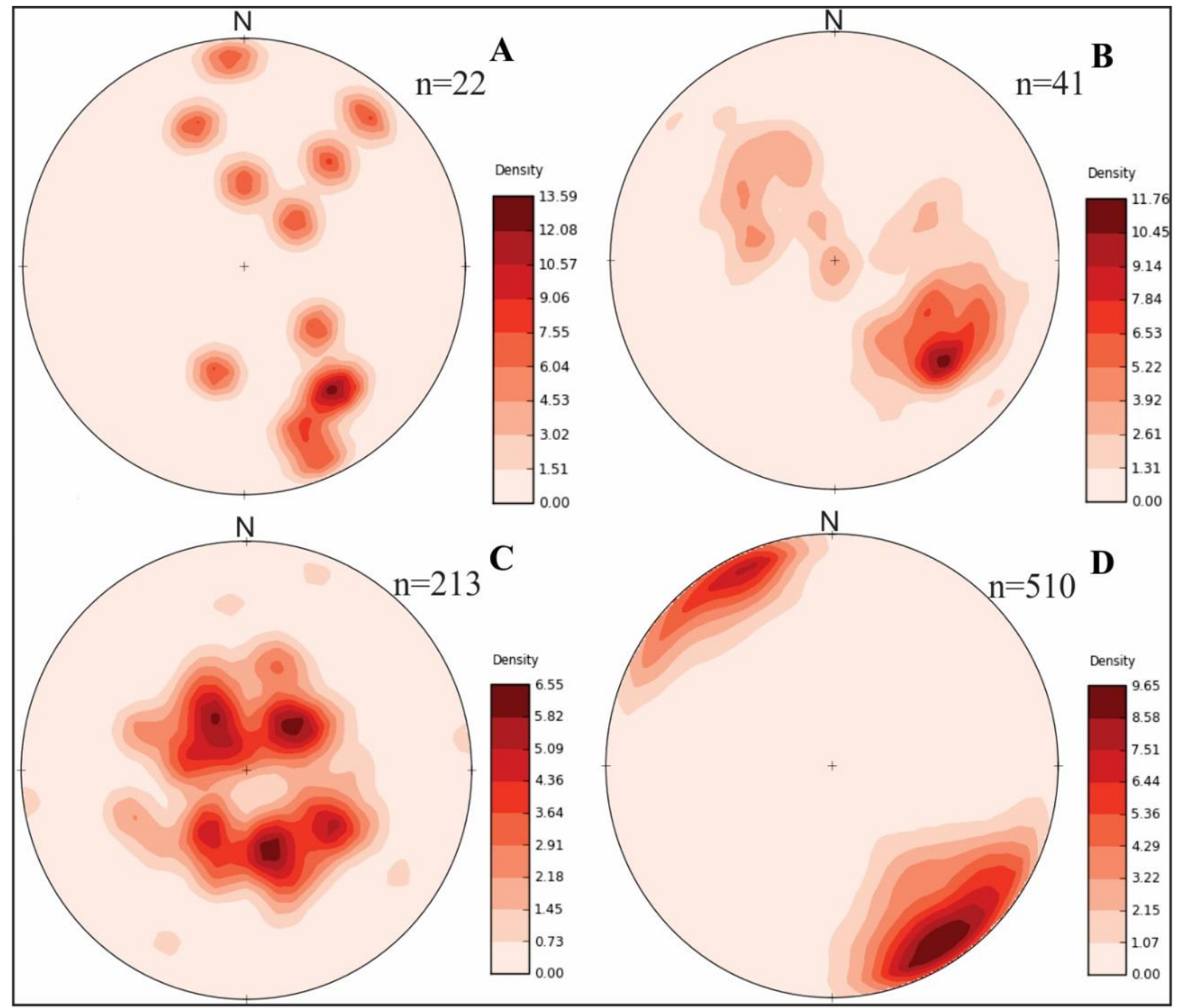

Figura 4 - Estereogramas da Folha Topográfica de Juquitiba: A) $S_{0}$; B) $S_{1}$ : N42E/53NW, C) $S_{2}$ : N10E/22SE, D) $S_{3}$ : N60E/subvertical. 


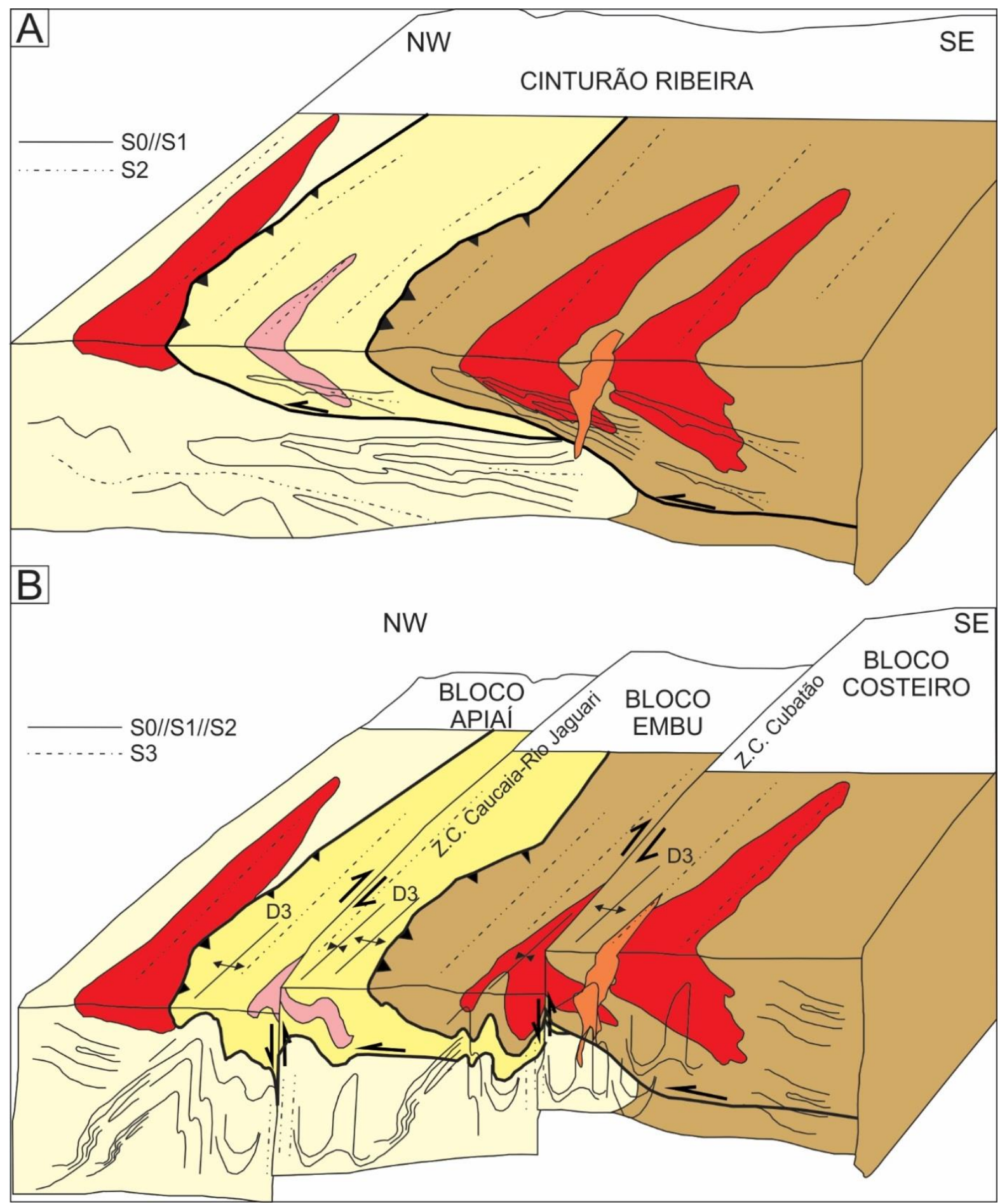

Figura 5 - Bloco diagrama da evolução do Terreno Embu. A) Fase colisional relativa ao Cinturão Ribeira durante regime compressivo, com geração de dobras isoclinais e foliações $S_{1}$ e $S_{2}$ de baixo ângulo. B) Padrão de redobramento para a área associado a uma deformação final de natureza transcorrente, com geração de dobras abertas, verticalização das foliações anteriores e geração de uma foliação $S_{3}$ de alto ângulo.

\section{CARACTERIZAÇÃO METAMÓRFICA}

Os eventos metamórficos identificados nas rochas que ocorrem na Folha Juquitiba apresentam uma evolução evidenciada pelo registro de três fases deformacionais $\mathrm{D}_{1}, \mathrm{D}_{2}, \mathrm{D}_{3}$, associadas aos eventos metamórficos $\mathrm{M}_{1}, \mathrm{M}_{2}, \mathrm{M}_{3}$ (Figura 6). Os eventos metamórficos são descritos principalmente nos litotipos paraderivados.

O metamorfismo pode ser caracterizado como dos tipos regional dinamotermal (Barroviano), de contato e dinâmico. O metamorfismo regional atinge a fácies anfibolito alto na zona da sillimanita para as rochas do Complexo Embu. Já o de contato está associado ao alojamento de granitos brasilianos e o dinâmico está associado a tectônica transcorrente brasiliana. 


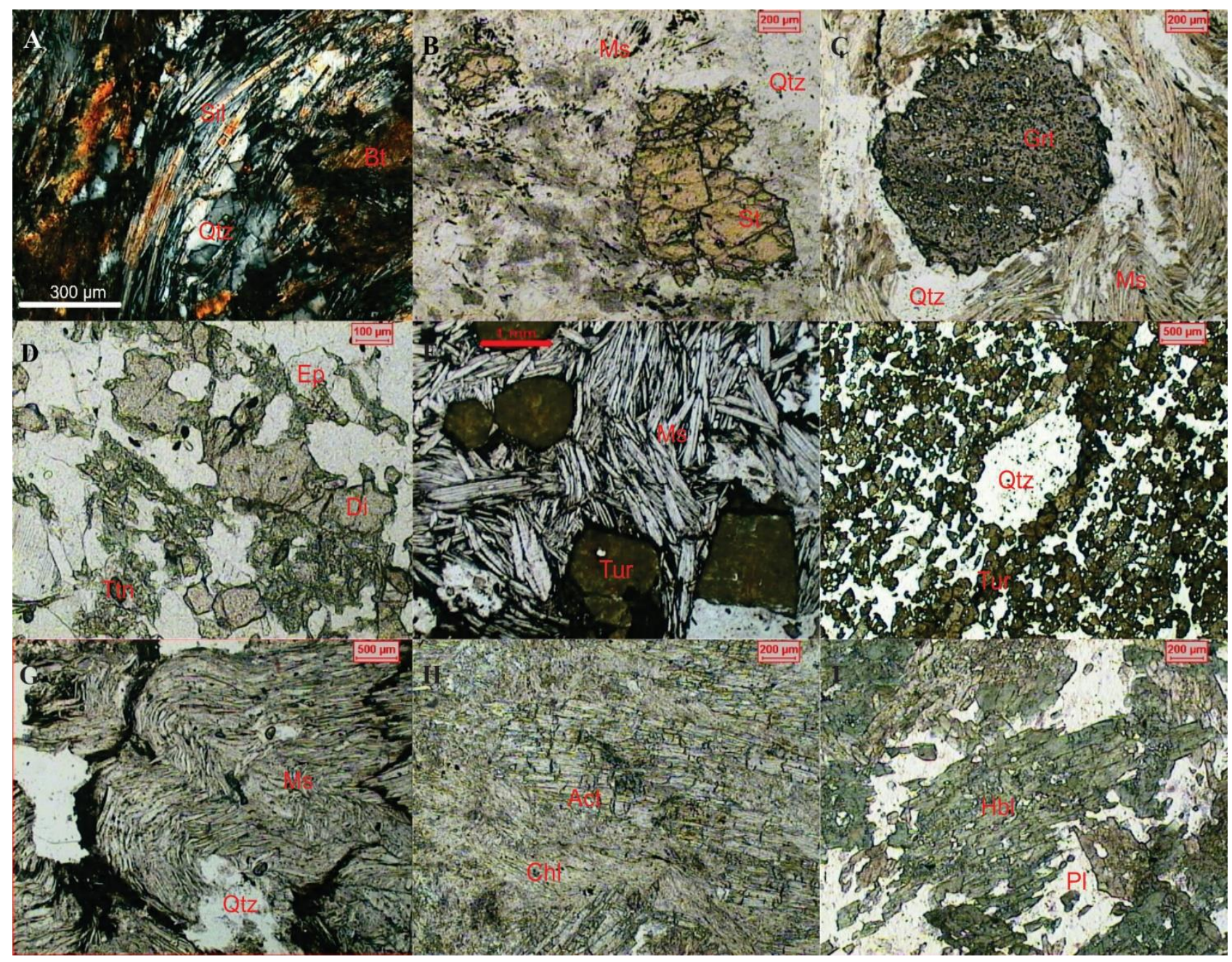

Figura 6 - Fotografias das principais feições mineralógicas e petrográficas das rochas na Folha Topográfica de Juquitiba. A) Sillimanita- biotita xisto, B) Estaurolita-muscovita xisto, C) Granada-muscovita xisto, D) Diopsídio calciossilicatada, E) Muscovita-turmalina xisto, F) Turmalinito, G) Muscovita-biotita xisto, H, I) Epidoto-actnolita-clorita xisto. Legenda: Qtz-quartzo, Tur-turmalina, Hbl-hornblenda, Ol-plagioclásio, Bt-biotita, Act-actinolita, Sil-silimanita, Ms-muscovita, Ep-epidoto, Tin-titanita, Chl-clorita, St-estaurolita, Grt-granada, Di-diopsídio.

O metamorfismo regional do Complexo Embu $\mathrm{M}_{1} / \mathrm{M}_{2}$ situa-se na fácies anfibolito médio a alto, zona de sillimanita-muscovita, através das associações granada + sillimanita +/- muscovita + biotita + feldspato potássico (Figura 6A), com fusão parcial para as rochas metassedimentares aluminosas, formando mobilizados graníticos. Entretanto, a presença de migmatitos como produto de anatexia destas sequências paraderivadas evidencia que a temperatura atingira valores iguais ou superiores a $650{ }^{\circ} \mathrm{C}$; podendo apresentar localmente gradações para a zona da sillimanita-ortoclásio com anatexia (605$770^{\circ} \mathrm{C}$ ) e às vezes para estaurolita + biotita + muscovita + sillimanita (fibrolita) + granada + microclínio (Figura 6B, C).

A paragênese encontrada na área (sillimanita + granada) indica um meta-morfismo progressivo $\mathrm{M}_{1}$ e $\mathrm{M}_{2}$ envolvendo Fe-estaurolita
+ granada + sillimanita, em um intervalo de temperatura de $580-680^{\circ} \mathrm{C}$ e em um intervalo de pressão de aproximadamente 5 a $7 \mathrm{~kb}$ (Figuras 6B, C). Paragêneses constituídas por andesina - labradorita + hornblenda para os anfibolitos e labradorita/bytownita + diopsídio/salita + escapolita + hornblenda + quartzo para as rochas calciossilicatadas são comuns (Figura 6D).

Como consequência das temperaturas e pressões alcançadas na fácies anfibolito, ocorreu a fusão parcial (anatexia) dos metassedimentos em profundidade, gerando corpos graníticos que ascenderam a níveis mesozonais em meio a xistos e gnaisses. Esses corpos graníticos sintectônicos a $\mathrm{D}_{2}$ resultou em um metamorfismo de contato às rochas encaixantes periféricas dessas intrusões, assim como a ação de fluidos hidrotermais e pneumatolíticos que formaram corpos pegma-títicos, turmalinização (Figuras 6E, 
F) e piritização.

As auréolas de metamorfismo termal apresentam-se parcialmente preservadas em função do menor grau de deformação imposto pelas zonas miloníticas nos contatos destes maciços, ou devidas à menor intensidade das transformações minerais retrometamórficas impostas pelo metamorfismo $\mathrm{M}_{3}$, que ocorre tanto nas paragêneses de contato como nas regionais.

Localmente, o metamorfismo dinâmico é intenso e vinculado a uma foliação milonítica e/ou cataclástica, com desenvolvimento de filonitos e bandamento tectônico que oblitera estruturas reliquiares e as estruturas deformacionais mais antigas. Atuam sobre os corpos graníticos, principalmente observado nas suas zonas marginais, próximo aos contatos com as rochas metassedimentares e, localmente, nas regiões internas do corpo por falhamentos direcionais, sempre com direção paralela às zonas de cisalhamento desen-volvidas no final da fase $\mathrm{D}_{3}$.

Os miloníticos distribuem-se em faixas NE e apresentam associações mineralógicas retrometamórficas constituídas por quartzo + muscovita + biotita + clorita, compatível com as condições de metamorfismo da fácies xisto verde, com temperaturas em torno de $450-500^{\circ} \mathrm{C}$ e pressões de cerca de 4 a $5 \mathrm{~kb}$.

Em algumas rochas, verifica-se que a sillimanita foi totalmente alterada para muscovita (Figura 6G), a cloritização de biotita, sericitização do feldspato, além da existência de clorita, muscovita, actinolita e epidoto (Figuras 6H, I). Este processo rúptil superpõe o conjunto das rochas, desestabilizando as paragêneses anteriores para condições da fácies xisto-verde baixa.

\section{CONCLUSÕES}

A área é dominada por litotipos rochosos de idade meso- a neoproterozoica, constituída por rochas metassedimentares do Complexo Embu: paragnaisses e xistos aluminosos migmatizados, rochas calciossilicatadas, mica xistos, anfibolitos e metarenitos. Intrusivo, ocorrem numerosos granitos e pegmatitos de idade neoproterozoica, os corpos peraluminosos do Tipo $\mathrm{S}$ e os corpos cálcio-alcalinos do Tipo I, referentes aos complexos Ibiúna e Caucaia, além de sedimentos quaternários recentes.

A evolução tectonometamórfica é marcada por deformações/metamorfismo progressivo $\mathrm{D}_{1} / 2$ tangenciais, associadas ao processo colisional, acompanhadas de metamorfismo progressivo $\mathrm{M}_{1} / \mathrm{M}_{2}$ superpostos pela tectônica transcorrente/transpressiva $\mathrm{D}_{3}$, marcada por uma foliação milonítica vertical de direção NE-SW, associado a processos de caráter retrometamórficos $\mathrm{M}_{3}$.

O metamorfismo regional é progressivo e do tipo Barroviano, com rochas em fácies anfibolito alto. Localmente observa-se a presença de metamorfismo de contato associado à fusão parcial e formação de mobilizados graníticos e migmatização associado a $\mathrm{M}_{1} / \mathrm{M}_{2}$ e dos granitos cálcioalcalinos e o metamorfismo dinâmico, de natureza retrometamórfica associado $\mathrm{M}_{3}$.

A evolução geológica da região inicia-se no Mesoproterozoico, com a deposição de uma sequência dominantemente terrígena, em bacia tipo rift, secundadas por sedimentos químicos e intrusivas básicas do Complexo Embu.

Durante o processo colisional neoproterozoico, ocorre uma deformação tangencial, associada à colocação de granitos aluminosos, que resultam, na maior parte, de um processo de anatexia dos paragnaisses e, posteriormente intrusivo à granitogênese ácida de natureza cálcio-alcalina.

$\mathrm{Na}$ fase final, as rochas foram submetidas gradativamente e de forma heterogênea ao retrometamorfismo.

Localmente, associado ao metamorfismo dinâmico, ocorrem a formação de corpos parcialmente ou totalmente tectonizados, vinculado a uma foliação milonítica e/ou cataclástica, com desenvolvimento de filonitos com bandamento tectônico que oblitera estruturas reliquiares e as estruturas deformacionais mais antigas, ou mesmo atuam sobre os corpos graníticos, principalmente observado nas suas zonas marginais próximo aos contatos com as rochas metassedimentares e localmente nas regiões internas do corpo por falhamentos direcionais, sempre com direção paralelas às zonas de cisalhamento desenvolvidas no final da fase $\mathrm{D}_{3}$.

Este processo rúptil superpõe o conjunto das rochas, desestabilizando as paragêneses anteriores para condições de fácies xisto-verde baixa. 


\section{AGRADECIMENTOS}

Os autores agradecem ao apoio da Companhia de Pesquisa de Recursos Minerais - CPRM e ao CNPq proc. $\mathrm{n}^{\mathrm{o}}: 304614 / 2017-3$.

\section{REFERÊNCIAS}

ALKMIM, F.F.; BRITO NEVES, B.B.; ALVES, J.A.C. Arcabouço tectônico do Cráton São Francisco: uma revisão. In: ALGARTE, J.P.; MARTINS, A.J.M.; MORGENTAL, A.; DAITX, E. C.; ANDRADE Jr, F.S.; BATOLLA Jr.F.; FERREIRA， F.J.F.; PINTO， G.G.; CUNHA， H.C.S.; DRUMOND, J.B.V., RODRIGUES, J.C.; YAMAMOTO, K.; KAEFER, L.Q.; CHIEREGATI, L.A.; PINHO FILHO, W.D.; ADDAS, W. Projeto Sudeste do Estado de São Paulo. Relatório Final. São Paulo: DNPM/CPRM, 1973

ALMEIDA, F.F.M. Considerações sobre a geomorfogênese da Serra do Cubatão. Boletim Paulista Geografia, v. 15, p. 3-17, 1953.

ALMEIDA, F.F.M. Origem e evolução da Plataforma Brasileira. Rio de Janeiro, DNPM-DGM. Boletim 241, 36p., 1967.

ALMEIDA, F.F.M. \& HASUI, Y. O Pré-Cambriano do Brasil. São Paulo, Blücher, 378p., 1984.

ALMEIDA, F.F.M.; HASUI, Y.; NEVES, B.B.B.; FUCK, R.A. Províncias Estruturais Brasileiras. In: SIMPÓSIO DE GEOLOGIA DO NORDESTE, 8, 1977, Campina Grande. Atas...Campina Grande: Sociedade Brasileira de Geologia, p. 363-91, 1977.

ALMEIDA, F.F.M.; HASUI, Y.; BRITO NEVES, B.B.B.; FUCK, R.A. Brazilian structural provinces: an introduction. Earth Sciences Reviews, v. 17, p. 1-29, 1981.

ALVES, A.; JANASI, V.A.; CAMPOS NETO, M.C.; HEAMAN, L.; SIMONETTI, A. U-Pb geochronology of the granite magmatism in the Embu Terrane: Implications for the evolution of the Central Ribeira Belt, SE Brazil. Precambrian Research, v. 230, p. 1-12, 2013.

ALVES, A.V.; JANASI, A.; CAMPOS NETO, M.C. Sources of granite magmatism in the Embu Terrane (Ribeira Belt, Brazil): Neoproterozoic crust recycling constrained by elemental and isotope ( $\mathrm{Sr}-\mathrm{Nd}-\mathrm{Pb})$ geochemistry. Journal of South American Earth Sciences, v. 68, p. 205-223, 2016.

BISTRICHI, C.A.; CARNEIRO, C.D.R.; DANTAS, A.S.L.; PONÇANO, W.L.; CAMPANHA, G. A.C.; NAGATA, N.; ALMEIDA, M.A.; STEIN, D.P.; MELO, M.S; CREMONINI, O.A. Mapa geológico do Estado de São Paulo, escala 1:500.0000. Instituto de Pesquisas Tecnológicas, São Paulo, Pub. 1184, 126p, 1981.

CAMPANHA, G.A.C. Tectônica Proterozoica no Alto e Médio Vale do Ribeira, Estados de São Paulo e Paraná. São Paulo, 1991. 296p. Tese (Doutorado), Instituto de Geociências-Universidade de São Paulo.

CAMPANHA, G.A.C. O papel do sistema de zonas de cisalhamento transcorrentes na configuração da porção meridional da Faixa Ribeira. São Paulo. 2002. 105p. Tese (Livre-Docência), Instituto de Geociências - Universidade de São Paulo.

CAMPANHA, G.A.C. \& SADOWSKI, G.R. Tectonics of the southern portion of the Ribeira Belt (Apiaí Domain). Precambrian Research, v. 98, p. 31-51, 1999.

CAMPOS NETO, M.C. Orogenic systems from southwestern Gondwana: an approach to Brasiliano-Pan African cycle and collage in southeastern Brazil. In: CORDANI, U.G.; MILANI, E.J.; THOMAZ FILHO, A.; CAMPOS, D.A. (Eds.), Tectonic Evolution of South America, p. 335-365, 2000.

CAMPOS NETO, M.C. \& BASEI, M.A.S. Evolução estrutural brasiliana do nordeste de São Paulo: dobramentos superpostos e esboço estratigráfico e tectônico. In: SIMPÓSIO
REGIONAL DE GEOLOGIA, 4, 1983, São Paulo. Atas... São Paulo: Sociedade Brasileira de Geologia, 1983, v. 1, p. 61-78, CAMPOS NETO, M.C. \& FIGUEIREDO, M.C. The Rio Doce Orogeny, Southeastern Brazil. Journal of South America Earth Sciences, v. 8, p. 143-162, 1995.

CAMPOS NETO, M.C., BASEI, M.A.S., ALVES, F.R., VASCONCELOS, A.C.B. A Nappe de Cavalgamento Socorro. In: CONGRESSO BRASILEIRO DE GEOLOGIA, 33, 1984, Rio de Janeiro. Anais... Rio de Janeiro: Sociedade Brasileira de Geologia, 1984, v. 4, p. 1809-1822.

CHIEREGATI, L.A.; SILVA, A.A.G.P.; OSTAFIUC, G.B.; MOTA FILHO, J.; ALEGRI, V.; SILVA, V.A.; SILVA, M.E.; FRANCISCONI, Ó.; YAMATO, A.A.; ALGARTE, J.P.; CÓ, A.E.O.; MINORELLI, D.; GOUVEIA, J.C.; SHIMAMOTO, R.Y. Projeto Integração Geológica da Região Metropolitana de São Paulo. Relatório de Integração Geológica. Relatório Final. São Paulo: CPRM, 1991.

CORDANI, U.G.; DELHAL, J.; LEDENT, O. Orogenèses superposeés dans le Précambrien du Brésil sud-oriental (États du Rio de Janeiro et de Minas Gerais). Revista Brasileira de Geociências, v. 3, n. 1, p. 1-22, 1973.

CORDANI, U.; COUTINHO, J.M.; NUTMAN, A. Geochronological constraints on the evolution of the Embu Complex, São Paulo, Brazil. Journal of South America Earth Sciences, v. 14, p. 903-910, 2002.

COUTINHO, J.M.V. O Falhamento de Cubatão. In: CONGRESSO BRASILEIRO DE GEOLOGIA, 25, 1971, São Paulo. Resumos...São Paulo: Sociedade Brasileira de Geologia, 1971, p. 130-1-31.

COUTINHO, J.M.V. Petrografia do Pré-Cambriano de São Paulo e arredores. São Paulo, Boletim USP/IG, p. 5-99, 1972.

DANTAS, A.S.L.; GIMENEZ FILHO, A.; NAGATA, N.; FERNANDES, L.A.; TEIXEIRA, A.L.; FRASCÁ, M.H.B. O. Evolução geológica e estrutural da faixa costeira nas regiões de Juquiá e Miracatu, sul do Estado de São Paulo. In: SIMPÓSIO REGIONAL DE GEOLOGIA, 6, 1987, Rio Claro. Atas... Rio Claro: Sociedade Brasileira de Geologia, v. 1, p. 173-189.

DANTAS, E.L.; HACKSPACHER, P.C.; GODOY, A.M.; SATO, K.; PIMENTEL, M.M.; OLIVEIRA, M.A.F.; FETTER, A. Characterization of the generating sources of continental crust of the Ribeira Belt through isotopes of $\mathrm{Nd}$ in the state of São Paulo, SE of Brazil. In: SIMPÓSIO SUDAMERICANO DE GEOLOGIA ISOTÓPICA E SOUTH AMERICAN SYMPOSIUM ON ISOTOPE GEOLOGY, 2, 1999, Córdoba. Atas...Cordoba: Instituto de Geologia y Recursos Minerales, v. 1. p. 192-195.

DANTAS, E.L.; HACKSPACHER, P.C.; FETTER, A.H.; SATO, K., PIMENTEL, M.M.; GODOY, A.M. ND Isotope Systematics Related to Proterozoic Evolution of the Central Ribeira Belt in the State of São Paulo, SE Brazil. Revista Brasileira de Geociências, v. 30, n. 1, p. 140-143, 2000.

FALEIROS, F.M. Evolução de Terrenos TectonoMetamórficos da Serrania do Ribeira e Planalto do Alto Turvo (SP, PR), São Paulo. São Paulo, 2008, 306 p. Tese (Doutorado), Instituto de Geociências - Universidade de São Paulo.

FALEIROS, F.M.; CAMPANHA, G.A.C.; BELLO, R.M.S.; FUZIKAWA, K. Quartz recrystallization regimes, c-axis texture transitions and fluid inclusion re-equilibration in a prograde greenschist to amphibolite facies mylonite zone 
(Ribeira Shear Zone, SE Brazil). Tectonophysics, v. 485, p. 193-214, 2010.

FALEIROS, F.M.; FERRARI, V.C.; COSTA, V.S.; CAMPANHA, G.A.C. Geoquímica e petrogênese de metabasítos do grupo Votuverava (Terreno Apiaí, Cinturão Ribeira Meridional): evidências de uma bacia retro arco caliminiana. Geologia USP, Série Científica, v. 11, n. 2, p. 135-155, 2011.

GODOY, A.M.; ZANARDO, A.; ARTUR, A.C.; OLIVEIRA, M.A.F.; MORALES N.; HACKSPACHER, P.C.; GALEMBECK, T.M.B. Rochas Granitóides da Folha São Roque-SP. In: CONGRESSO BRASILEIRO GEOLOGIA, 37, 1992, São Paulo. Anais...São Paulo, Sociedade Brasileira de Geologia, p. 356-357.

GODOY, A.M.; OLIVEIRA, M.A.F.; HACKSPACHER, P.C. Geoquímica das Rochas Granitóides da Folha São Roque-SP. São Paulo, UNESP, Geociências, v. 15, $\mathrm{n}^{0}$ especial, p. 67 -88, 1996

GODOY, A.M.; HACKSPACHER, P.C.; OLIVEIRA, M.A.F.; GOMES, A.B. Geoquímica dos Maciços Granitóides Ibiúna e Piedade na Folha Sorocaba. São Paulo, UNESP, Geociências, v. 18, n.1, p. $157-178,1999$.

GOMES, A.B. \& GODOY, A.M. Geoquímica e Terras Raras da Porção Norte do Maciço Granitoide Ibiúna, SE do Estado de São Paulo. In: CONGRESSO BRASILEIRO DE GEOLOGIA, 41, 2002, João Pessoa. Anais...João Pessoa: Sociedade Brasileira de Geologia, v. 1, p. 112.

HACKSPACHER, P.C. \& GODOY, A.M. Vertical Displacement During Post-Colisional Escape Tectonic (Brasiliano Orogeny) of The Ribeira Belt, São Paulo, Brazil. Elsevier Science Ltda., Africa do Sul. Journal of African Earth Sciences, v. 29, n. 1, p. 25-32, 1999.

HACKSPACHER, P.C.; OLIVEIRA, M.A.F.; GODOY, A.M. Controle do Nível Metamórfico e da Disposição dos Corpos Granitóides pela Tectônica Dn+3/Transcorrente na Folha Cabreúva. In: SIMPÓSIO GEOLOGIA SUDESTE, 2, 1991, São Paulo. Anais... São Paulo: Sociedade Brasileira de Geologia, v. 1, p. 151-154.

HACKSPACHER, P.C.; MORALES, N.; ZANARDO, A.; GODOY, A.M.; OLIVEIRA, M.A.F; ARTUR, A.C. A Tectônica Transcorrente - Transpressiva Brasiliana da Folha São Roque - SP. In: CONGRESSO BRASILEIRO DE GEOLOGIA, 37, 1992, São Paulo. Anais...São Paulo: Sociedade Brasileira de Geologia, v. 2, p. 348-49.

HACKSPACHER, P.C.; GODOY, A.M.; OLIVEIRA, M.A.F. Evolução Crustal do bloco São Roque, na região sudeste do Estado de São Paulo. São Paulo, UNESP, Geociências, v. 23, n. 3, p. 260-64, 1993.

HACKSPACHER, P.C.; DANTAS, E.L.; GODOY, A.M.; OLIVEIRA, M.A.F.; FETTER, A.; SCHMUS, W.R. VAN. Considerations about the evolution of the Ribeira Belt in the Sao Paulo State, Brazil, from U/Pb geochronology in metavolcanic rocks of the Sao Roque Group. In: $2^{\circ}$ SIMPÓSIO SUDAMERICANO DE GEOLOGIA ISOTÓPICA E SOUTH AMERICAN SYMPOSIUM ON ISOTOPE GEOLOGY, $2^{\circ}$, 1999, Córdoba. Atas...Córdoba-Argentina: Instituto de Geologia e Recursos Minerais, 1999, v. 1. p. 310-313.

HACKSPACHER, P.C.; DANTAS, E.L.; SPOLADORE, A.; FETTER, A.H.; OLIVEIRA, M.A.F. Evidence of Neoproterozoic Backarc Basin development in the central Ribeira Belt, Southeastern Brazil: new geochronological and geochemical constraints from the São Roque - Açunguí Groups. Revista Brasileira de Geociências, v. 30, n. 1, p. 110114,2000

HASUI, Y. Tectônica da Área das Folhas de São Roque e Pilar do Sul. São Paulo, 1973. 189p. Tese (Livre Docência), Instituto de Geociências-Universidade de São Paulo.

HASUI, Y. Evolução Polifásica do Pré-Cambriano a Oeste de São Paulo. Boletim do IG/USP, v. 6, p. 95-108, 1975.
HASUI, Y. A grande colisão pré-cambriana do Sudeste Brasileiro e a estruturação regional. São Paulo, UNESP, Geociências, v. 29, n. 2, p. 141-169, 2010.

HASUI, Y. Sistema Orogênico Mantiqueira. In: HASUI, Y., CARNEIRO, C.D.R., ALMEIDA, F.F.M., BARTORELLI, A. (Org.). Geologia do Brasil. São Paulo, Editora Beca, p. 331372, 2012.

HASUI, Y. \& SADOWSKI, G.R. Evolução Geológica do PréCambriano na Região Nordeste do Estado de São Paulo. Revista Brasileira de Geociências, v. 6, n. 3, p. 182-200, 1976.

HASUI, Y. \& OLIVEIRA, M.A.F. Província Mantiqueira - Setor central. In: F.F.M. ALMEIDA, Y. HASUI. (Eds). O PréCambriano do Brasil. São Paulo: Blücher, p. 308-344, 1984.

HASUI Y.; PENALVA, F.; HENNIES, W.T. Geologia do Grupo São Roque. In: CONGRESSO BRASILEIRO DE GEOLOGIA, 23, 1969, Salvador. Anais... Salvador: Sociedade Brasileira de Geologia, 1969, v. 1, p. 101-134.

HASUI, Y.; SADOWSKI, G.R.; CARNEIRO, C.D.R. Considerações sobre a Estratigrafia do Pré-Cambriano na Região de São Paulo. São Paulo, Boletim do IG/USP, v.7, p.107-12,1976.

HASUI, Y.; CARNEIRO, C.D.R.; BISTRICHI, C.A. Os granitos e granitóides da região de dobramentos Sudeste nos Estados de São Paulo e Paraná. In: CONGRESSO BRASILEIRO DE GEOLOGIA, 30, 1978, Recife. Anais...Recife: Sociedade Brasileira de Geologia, 1978. v. 6, p. 2594-608

HASUI, Y; DANTAS, A.S.L; CARNEIRO, C.D.R; BISTRICH, C.A. O embasamento Pré-Cambriano e Eo-Paleozóico em São Paulo. Mapa Geológico do Estado de São Paulo, Escala 1.500.000. São Paulo, SP, Brasil, 1: 12-45, 1981.

HEILBRON, M.; VALERIANO, C.M.; VALLADARES, C.S.; MACHADO, N. A Orogênese Brasiliana no segmento central da Faixa Ribeira, Brasil. Revista Brasileira de Geociências, v. 25 , n. 4 , p. 249-266, 1995.

HEILBRON, M.; PEDROSA-SOARES, A.C.; CAMPOS NETO, M.C.C.; SILVA, L.C.; TROUW, R.A.J.; JANISI, V.A. Província Mantiqueira. In: MANTESSO-NETO, V.; BARTORELLI, A.; CARNEIRO, C.D.R.; BRITO-NEVES, B.B. (eds.) Geologia do Continente Sul-Americano: Evolução da Obra de Fernando Flávio Marques de Almeida. Ed. Beca. São Paulo. p. 203-235, 2004.

HENNIES, W.T.; HASUI, Y.; PENALVA, F. O Falhamento Transcorrente de Taxaquara. In: CONGRESSO BRASILEIRO GEOLOGIA, 21, 1967, Curitiba. Anais... Curitiba: Sociedade Brasileira de Geologia, 1967. p. 159-168.

INSTITUTO GEOGRÁFICO GEOLÓGICO (IG). Mapa geológico do Estado de São Paulo, em 1: 1.000 .000 , São Paulo, 1963.

INSTITUTO GEOGRÁFIC0 GEOLÓGIC0 (IG). Mapa Geológico do Estado de São Paulo, em 1:1.000,000. São Paulo, 1974.

JANASI, V.A. \& ULBRICH, H.H.G.J. Late Proterozoic granitoid magmatism in the State of São Paulo, southeastern Brazil. Precambrian Resarch, v. 51, p. 351-374, 1991.

JANASI, V.A. \& ULBRICH, H.H.G.J. Inventário Bibliográfico de Granitos do Estado de São Paulo. Boletim Instituto de Geociências. Publicação Especial, v. 11, 253p. 1992.

JANASI, V.A.; VASCONCELOS, A.C.B.C.; VLACH, S.R.F.; MOTIDOME, M.J. Granitóides da região entre as cidades de São Paulo e Piedade (SP): faciologia e contexto tectônico. In: Congresso Brasileiro de Geologia, 36, 1990, Natal. Anais...Natal: Sociedade Brasileira de Geologia, 1990. v. 4, p. 1925-35.

JANASI, V.A.; ALVES, A.; VLACH, S.R.F.; LEITE, R.J. Granitos Peraluminosos da porção Central da Faixa Ribeira, Estado de São Paulo: Sucessivos Eventos de Reciclagem da Crosta Continental no Neoproterozoico. Geologia USP - Série Científica. v. 3, p. 13-24, 2003. 
LEITE, R.J. Geologia, Petrografia e Geoquímica dos Granitóides da Região de Piedade, SP. São Paulo, 1997. 138p. Dissertação (Mestrado), Instituto de GeociênciasUniversidade de São Paulo.

MAURER, V.C. Caracterização geocronológica (U-Pb), geoquímica e isotópica ( $\mathrm{Sr}, \mathrm{Nd}$, Hf) do Complexo Rio Capivari no Terreno Embu. São Paulo, 290p., 2016. Dissertação (Mestrado), Instituto de Geociências Universidade de São Paulo.

MEIRA, V.T. Evolução tectono-metamórfica Neoproterozoica dos complexos Embu e Costeiro no contexto de formação do Gondwana ocidental (leste do estado de São Paulo). São Paulo, 2014, 266p. Tese (Doutorado), Instituto de Geociências - Universidade de São Paulo.

OLIVEIRA, M.A.F.; GODOY, A.M.; HACKSPACKER, P.C.; MORALES, N. Geologia da Folha São Roque, SP - 1:50.000. São Paulo, UNESP, Geociências, v. 17, n. 2, 1998.

PASSARELLI, C.R.; BASEI, M.A.S.; CAMPOS NETO, M.C.; SIGA JÚNIOR, O.; PRAZERES FILHO, H.J. Geocronologia e Geologia Isotópica dos Terrenos Pré-Cambrianos da Porção Sul-Oriental do Estado de São Paulo. Geologia USP - Série Científica, v. 4, n. 1, p. 55- 74, 2004.

PERROTTA, M.M.; SALVADOR, E.D.; LOPES, R.C.; D'AGOSTINHO, L.Z.; PERUFFO, N.; GOMES, S.D.; SACHS, L.L.; MEIRA, V.T.; GARCIA, M.G.M.; LACERDA FILHO, J.V. Mapa Geológico do Estado de São Paulo, escala 1:750.000. Programa Geologia do Brasil - PGB, CPRM, São Paulo, 2005.

PRAZERES FILHO, H.J.; HARARA, O.M.; BASEI, M.A.S.; PASSARELLI, C.R.; SIGA JUNIOR, O. Litoquímica, geocronologia $\mathrm{U}-\mathrm{Pb}$ e geologia isotópica ( $\mathrm{Sr}-\mathrm{Nd}-\mathrm{Pb})$ das rochas graníticas dos batólitos Cunhaporanga e Três Córregos na porção sul do Cinturão Ribeira, Estado do Paraná. Geologia USP, Série Científica, v. 3, p. 51-70, 2003.

SADOWSKI, G.R. Tectônica da Serra de Cubatão, SP. São Paulo, 1974. Tese (Doutorado), Instituto de Geociências Universidade de São Paulo.

SANTOS, T.M.B.; TASSINARI, C.C.G; FONSECA, P.E. Diachronic collision, slab break-off and long-term high thermal flux in the Brasiliano-Pan-African orogeny: Implications for the geodynamic evolution of the Mantiqueira Province. Precambrian Research, v. 260, p. 1-22, 2015.
SILVA, B.Y.B. Evolução Tectônica da Porção Central do Terreno Embu ao norte da Zona de Cisalhamento Taxaquara-Guararema. São Paulo, 2017, 122p. Tese (Doutorado), Instituto de Geociências-Universidade de São Paulo.

SOBREIRO NETO, A.F.; PAIVA FILHO, A.; MORTARI, J.L.; BITAR, O.Y. Geologia da Folha São Luiz do Paraitinga (SP). In: JORNADA SOBRE A CARTA GEOLÓGICA DO ESTADO DE SÃO PAULO EM 1:50.000, 1983, São Paulo. Atas... São Paulo: Pro-Minério/IPT, 1983. p. 31-52.

TASSINARI, C.C.G. As Idades das Rochas e dos Eventos Metamórficos da Porção SE do Estado de São Paulo e sua Evolução Crustal. São Paulo, 1988. 236p. Tese (Doutorado), Instituto de Geociências - Universidade de São Paulo.

TASSINARI, C.C.G. \& CAMPOS NETO, M.C. Precambrian Continental crust evolution of Southeastern São Paulo State Brazil: Based on isotopic evidences. Geochimica Brasiliensis, v. 2 , n. 2 , p. $175-183,1988$.

VIEIRA, S.R.S.S. Estudo Litoestrutural da Região de Embu Guaçu - Parelheiros, São Paulo. São Paulo, 1989, 123p. Tese (Mestrado), Instituto de Geociências-Universidade de São Paulo

Vieira, S.R.S.S. \& Tassinari, C.C.G. Estudo petrológico e geocronológico das rochas da região de Embu-Guaçu, Estado de São Paulo. In: CONGRESSO BRASILEIRO DE GEOLOGIA, 35, 1988, Belém. Anais...Belém: Sociedade Brasileira de Geologia, v. 3, p. 1391-1399.

Vlach, S.R.F. Microprobe monazite constraints for an early ( $c a$. $790 \mathrm{Ma}$ ) Brasiliano orogeny: The Embú Terrane, Southeastern Brazil. In: SIMPOSIO SUDAMERICANO EN GEOLOGIA ISOTÓPICA, 3, 2001, Pucón. Extended Abstracts...Pucón: 2001, p. 265-268

VLACH, S.R.F.; JANASI, V.A.; VASCONCELLOS, A.C.B.C. The Itú Belt: associated calc alkaline and aluminous a-type late Brasiliano granitoids in the states of São Paulo and Paraná, southern Brazil. In: CONGRESSO BRASILEIRA DE GEOLOGIA, 36, 1990, Natal. Anais...Natal: Sociedade Brasileira de Geologia, v. 4, p. 1700-1711, 1990.

Submetido em 14 de março de 2018 Aceito 25 de julho de 2018 